\title{
Aminopyrazolo[1,5-a]pyrimidines as potential inhibitors of Mycobacterium tuberculosis: Structure activity relationships and ADME characterization
}

\author{
Candice Soares de Melo, ${ }^{a}$ Tzu-Shean Feng, ${ }^{a}$ Renier van der Westhuyzen, ${ }^{a}$ Richard K. \\ Gessner, ${ }^{a}$ Leslie J. Street, ${ }^{a}$ Garreth L. Morgans, ${ }^{b}$ Digby Warner, ${ }^{c, d}$ Atica Moosa, ${ }^{d}$ Krupa \\ Naran, ${ }^{d}$ Nina Lawrence, ${ }^{e}$ Helena I.M Boshoff, ${ }^{f}$ Clifton E. Barry $3^{\text {rd } f}$, C. John Harris, ${ }^{g}$ \\ Richard Gordon $^{h}$ and Kelly Chibale ${ }^{a, c, i^{*}}$ \\ ${ }^{a}$ Drug Discovery and Development Centre (H3D), Department of Chemistry, University of Cape Town, Rondebosch 7701, \\ South Africa* \\ ${ }^{b}$ iThemba Pharmaceuticals, Modderfontein 1609, South Africa \\ ${ }^{c}$ MRC/NHLS/UCT Molecular Mycobacteriology Research Unit, Department of Clinical Laboratory Sciences, University of \\ Cape Town, Rondebosch 7701, South Africa \\ ${ }^{c}$ Institute of Infectious Disease and Molecular Medicine, University of Cape Town, Rondebosch 7701, South Africa \\ ${ }^{e}$ Division of Clinical Pharmacology, University of Cape Town, Rondebosch 7701, South Africa \\ ${ }^{f}$ Tuberculosis Research Section, Laboratory of Clinical Infectious Diseases, National Institute of Allergy and Infectious \\ Diseases, National Institutes of Health, Bethesda, Maryland 20892, United States \\ ${ }^{g}$ Cjh Consultants (Pharmaceutical R\&D), Lydith, High Street, Eynsford, Kent, DA4 OAB, United Kingdom \\ ${ }^{h}$ Strategic Health Innovation Partnerships (SHIP), South African Medical Research Council, Parow Valley, South Africa \\ ${ }^{i}$ South African Medical Research Council Drug Discovery and Development Research Unit, University of Cape Town, \\ Rondebosch 7701, South Africa.
}

Whole-cell high-throughput screening of a diverse SoftFocus library against Mycobacterium tuberculosis $(M t b)$ generated a novel aminopyrazolo[1,5-a]pyrimidine hit series. The synthesis and structure activity relationship studies identified compounds with potent antimycobacterial activity. The SAR of over 140 compounds shows that the 2pyridylmethylamine moiety at the $\mathrm{C}-7$ position of the pyrazolopyrimidine scaffold was important for $M t b$ activity, whereas the C-3 position offered a higher degree of flexibility. The series was also profiled for in vitro cytotoxicity and microsomal metabolic stability as well as physicochemical properties. Consequently liabilities to be addressed in a future lead optimization campaign have been identified.

\section{Introduction}

Tuberculosis (TB) is the second leading cause of death from a single infectious agent after HIV. According to the World Health Organization 2014 report, it is estimated that there were 9.0 million new TB cases and 1.5 million lives were lost to the disease in $2013 .^{1}$ There is no universally effective vaccine against infection by Mycobacterium tuberculosis (Mtb), the causative pathogen, ${ }^{2}$ and an estimated one-third of the world's population already harbours latent TB of which an estimated $10 \%$ will develop active disease during their lifetime, rendering eradication near impossible. ${ }^{3}$ First-line TB chemotherapy involves the use of four drugs (rifampicin, isoniazid, ethambutol, and pyrazinamide) administered over a 2 month intensive phase, followed by a further 4 month continuation phase using only rifampicin and isoniazid. ${ }^{4}$ Limitations to the current regimen due to a range of adverse side-effects and prolonged treatment time has led to non-compliance in patients, inevitably resulting in resistant forms of the disease and patient relapse. The severe challenges to TB control brought by the increasing prevalence of multidrug-resistant (MDR) and extensively drug-

*Corresponding author. Tel.: +27 21 6502553; fax: +27 21 6505195; email: kelly.chibale@uct.ac.za 
resistant (XDR) TB, further exacerbated by HIV co-infection, have culminated in recent reports of emergent strains that are resistant to all known TB drugs. ${ }^{4}$ Moreover, of the estimated 480000 cases of MDR TB in 2013, a very small fraction were treated according to WHO standards, reflecting such diverse factors as low diagnosis rates, higher drug costs and longer treatment times, the use of less effective drugs that cause more toxic side effects leading to patient non-compliance, drug misuse through private sector availability in many high burden countries, and inadequate health-care oversight. ${ }^{1,2,5-8}$ There are a number of antiTB drug candidates in pre-clinical and clinical development ${ }^{9,10,11}$ and, in 2012, the first new drug in more than 40 years, bedaquiline (TMC207), was approved by the FDA for treatment of MDR TB through an accelerated approval process. ${ }^{12 a}$ However, there are major challenges to its wide-scale use for a variety of reasons. First, there is limited clinical data available. Second, its use is confined to carefully monitored settings in view of hepatotoxicity and cardiotoxicity safety concerns. Third, in many countries, patient eligibility is not predetermined since MDR patients typically commence treatment prior to receiving results of the often time consuming and expensive drug sensitivity tests. ${ }^{12 b, c}$ Therefore, there is an immediate need both for more effective and faster acting new therapies with novel mechanisms of action to simplify or replace the existing drug cocktails required for $\mathrm{TB}$ treatment. Aiding this goal is a shift in the paradigm of TB drug discovery with many pharmaceutical companies and academia exploring collaborative models by adopting an open source philosophy of conducting early-stage TB drug discovery research in order to address the need for new TB drugs. ${ }^{13}$ In this regard a diverse range of heterocyclic cores, which provide starting points for medicinal optimization have been disclosed. ${ }^{13}$ In addition, there have been improvements in both the in vitro and in vivo strategies employed for lead optimization in order to maximise the probability of developing clinical candidates. ${ }^{14}$

In order to find new lead compounds active against $M t b$, a 35,000 compound SoftFocus ${ }^{\mathrm{TM}}$ library was obtained from Biofocus and screened against the virulent $M t b \mathrm{H} 37 \mathrm{Rv}$ strain. High-throughput screening was carried out in liquid culture (7H9 medium) under aerobic conditions, using glucose as a carbon source. Whole-cell active compounds were selected from the screens using several criteria, including potency, intellectual property overlap, and chemical-structural properties. One of the libraries was designated SFK29 (SoftFocus Kinase) based on a 7-(aminomethyl)aryl pyrazolo[1,5-a]pyrimidine series, Figure 1. The diverse compound library represented more than 200 scaffolds that had primarily been designed as potential kinase inhibitors, GPCR antagonists, or ion channel modulators. The whole-cell screen confirmed that, of the 248 7-(aminomethyl)aryl pyrazolo[1,5-a]pyrimidines screened, six compounds showed Minimum Inhibitory Concentrations ( $\mathrm{MIC}_{99}$, representing 99\% growth inhibition) less than $5 \mu \mathrm{M}$.

Pyrazolo[1,5-a]pyrimidines are of chemical and pharmacological importance as purine analogues, and derivatives have been applied in various therapeutic areas such as antitumor, ${ }^{15-19}$ antidepressant, ${ }^{20-21}$ antibacterial, ${ }^{22}$ antiviral, ${ }^{23}$ antidiabetic ${ }^{24}$ and antihypertensive agents. ${ }^{25,26}$ Representatives of the SFK29 series (1-6, Figure 1) were selected for resynthesis based on their activities $\left(\mathrm{MIC}_{99}<5 \mu \mathrm{M}\right)$ and confirmatory testing 
against $M t b \mathrm{H} 37 \mathrm{Rv}$ in Middlebrook $7 \mathrm{H} 9$ broth, with $\mathrm{MIC}_{99}$, values after 14 days reported within an acceptable range of activity.

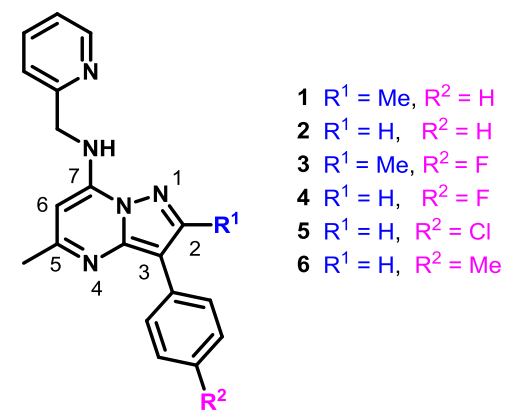

Figure 1. Structure of 7-(aminomethyl)arylpyrazolo[1,5-a]pyrimidine hits identified by $M t b$ phenotypic screening.

Based on its structural novelty, broad activity, and acceptable potencies, the aminopyrazolo[1,5-a]pyrimidine series was selected for a medicinal chemistry optimisation campaign. Herein, we present the synthesis, structure activity relationship (SAR), and in vitro Absorption, Distribution, Metabolism, Excretion (ADME) studies. Preliminary mode-ofaction studies are also presented.

\section{Chemistry}

SAR studies focused around substitution with a variety of amino groups in the 7-position, and aryl groups in the 3-position. Using 1 as the starting point, and with substituents at the 3position fixed as a phenyl, the 7-position was explored, to evaluate the importance of the pyridin-2-ylmethylamine substituent. The synthesis of the desired target compound 9 was carried out via advanced intermediate $\mathbf{8}$ as shown in Scheme 1, following a modified literature procedure. ${ }^{27} 7$-Hydroxypyrazolo[1,5-a] pyrimidine 7 was prepared in good yield from the acid-catalysed cyclisation of 5-amino-3-methyl-4-phenyl-1 $H$-pyrazole and ethyl 3oxobutanoate.

\section{Scheme 1. Synthesis of 7-substituted aminopyrazolo[1,5-a]pyrimidines ${ }^{a}$}

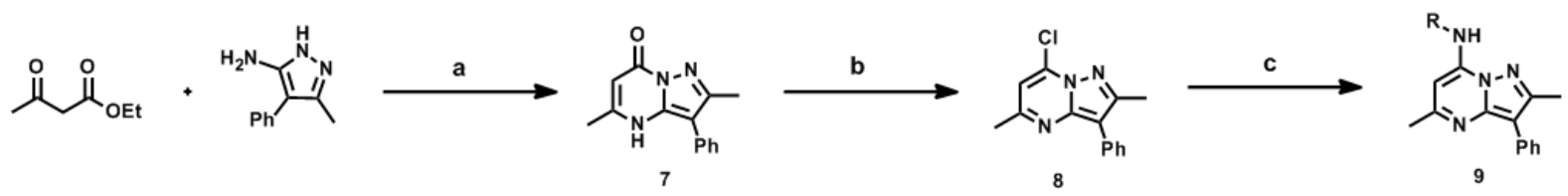

${ }^{a}$ Reagents and conditions: (a) $\mathrm{AcOH}$, reflux, 16h; (b) $\mathrm{POCl}_{3}$ (3 eq), $N, N$-Dimethylaniline (1.2 eq), toluene, $120^{\circ} \mathrm{C}, 16 \mathrm{~h}$; (c) $\mathrm{RNH}_{2}(1.2 \mathrm{eq})$, DiPEA (1.5 eq), $i \mathrm{PrOH}, 80^{\circ} \mathrm{C}, 16 \mathrm{~h}$.

Chlorination of 7 under standard conditions using phosphorous oxychloride afforded 7chloro-2,5-dimethyl-3-phenylpyrazolo[1,5-a]pyrimidine 8. Subsequent displacement of the chloro group with a range of amines under standard thermal conditions gave the desired compounds. Pyridin-2-ylmethylpyrazolo[1,5-a]pyrimidine derivatives 13, where the substituent $\left(\mathrm{R}^{1}\right)$ at the 2-position was either $\mathrm{H}$ or $\mathrm{Me}$, were prepared using a similar synthetic route via known 7-chloropyrazolo[1,5-a]pyrimidine ${ }^{28}(\mathbf{1 0})$ for investigation of the SAR at the 3-position (Scheme 2). Synthesis of intermediate 11 was completed by C-3 bromination using 
$N$-bromosuccinimide. Coupling of 2-picolylamine, followed by protection of the free amine with a tert-butoxycarbonyl group afforded advanced intermediate 12. Subsequent Suzuki coupling with an array of boronic acids gave the desired products $\mathbf{1 3}$ after deprotection.

\section{Scheme 2. Synthesis of 3-substituted aminopyrazolo[1,5-a]pyrimidines ${ }^{b}$}
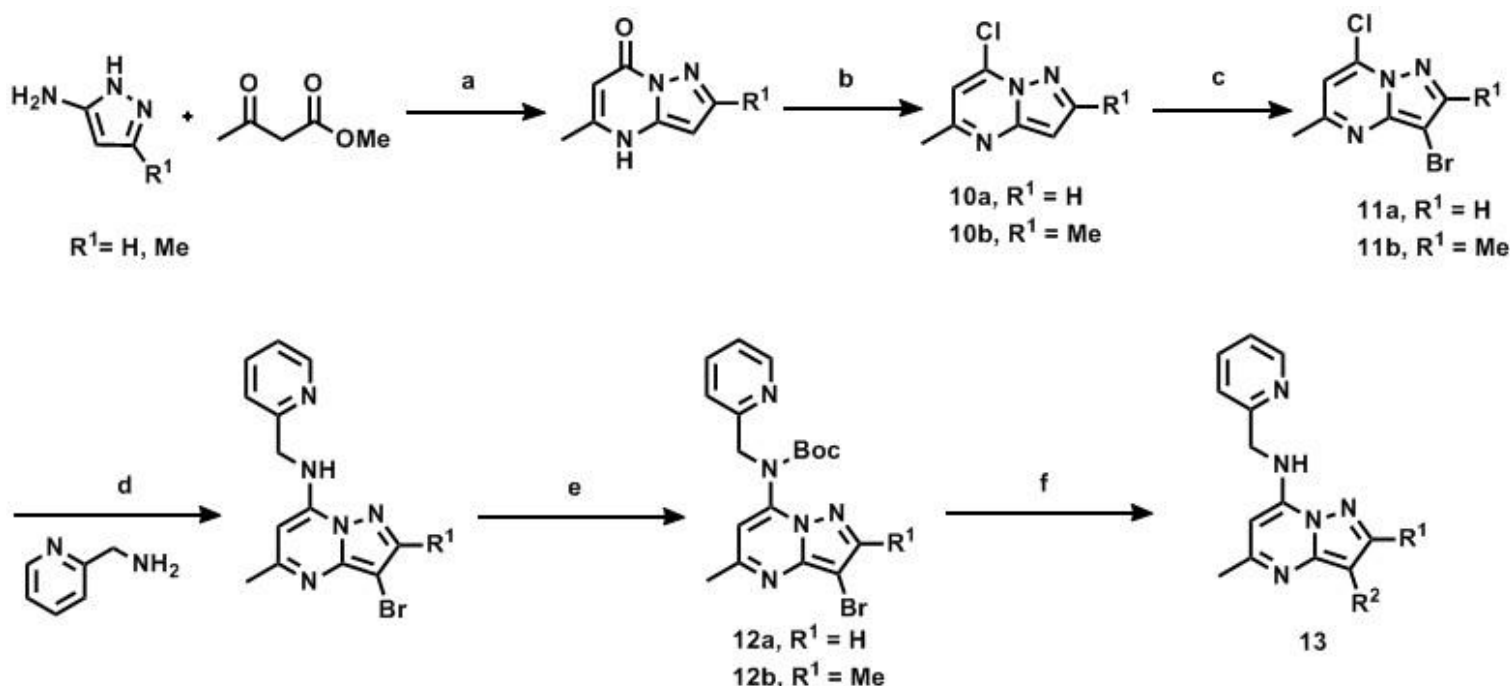

${ }^{b}$ Reagents and conditions: (a) AcOH, reflux, $10 \mathrm{~h}$; (b) $\mathrm{POCl}_{3}$ (3 eq), $N, N$-Dimethylaniline (1.2 eq), toluene, $120{ }^{\circ} \mathrm{C}, 16 \mathrm{~h}$; (c) NBS (1.1 eq), $\mathrm{CH}_{2} \mathrm{Cl}_{2}, 0{ }^{\circ} \mathrm{C}$ to rt, $16 \mathrm{~h}$; (d) 2-picolylamine (1.2 eq), DiPEA (1.5 eq), $i \mathrm{PrOH}, 80^{\circ} \mathrm{C}, 16 \mathrm{~h}$; (e) $(\mathrm{Boc})_{2} \mathrm{O}(1.5$ eq), DMAP (0.1 eq), DiPEA (1.5 eq), $\mathrm{CH}_{2} \mathrm{Cl}_{2}, \mathrm{rt}, 16 \mathrm{~h}$; (f) (i) $\mathrm{Ar}-\mathrm{B}(\mathrm{OH})_{2}$ (1.2 eq), $\mathrm{PdCl}_{2}$ (dppf) (0.1 eq), $\mathrm{Cs}_{2} \mathrm{CO}_{3}(1 \mathrm{eq})$, Dioxane, $\mathrm{H}_{2} \mathrm{O}, 80^{\circ} \mathrm{C}, 16 \mathrm{~h}$ (ii) TFA, DCM, $4 \mathrm{~h}$.

\section{Results and discussion}

A representative hit $\mathbf{1}$ identified from whole-cell screening displayed promising antimycobacterial activity ( $\mathrm{MIC}_{99}=5 \mu \mathrm{M}$ at day 14) but showed low kinetic solubility $(<5$ $\mu \mathrm{M}$ at $\mathrm{pH}$ 7.4) and poor metabolic stability in human liver microsomes (HLM $t_{1 / 2}=31.7 \mathrm{~min}$ ). Initial medicinal chemistry efforts focused on exploration of the $\mathrm{R}$ substituent at position 7 and the $\mathrm{R}^{1}$ substituent at position 3 to establish SAR (Tables 1 and 2). Profiling of compounds was carried out to determine aqueous solubility, hepatic microsomal stability, and mammalian cytotoxicity (Tables 3 and 4). The in vitro antimycobacterial activity for synthesised compounds was measured against M. tuberculosis H37RvMA (ATCC 27294 strain) ${ }^{29}$ using the broth microdilution method ${ }^{30}$ in both Middlebrook 7H9/ADC and GASTFe media.

\subsection{Modifications to the 7-position}

In order to determine the importance of the 7-pyridin-2-ylmethylamine substituent which featured in the hit compounds 1-6, analogues were synthesised using an array of commercially available amines and alcohols. The results for the antimycobacterial activity and kinetic solubility of a selection of synthesized compounds are presented in Table 1 . The 2-pyridyl ring was shown to be essential for antimycobacterial activity. The 3-pyridyl (14) 
and 4-pyridine (15) derivatives resulted in complete loss of Mtb activity (MIC99 $>160 \mu \mathrm{M}$ ). However, the pyrimidine (16) and pyrazine (17) analogues retained some $M t b$ activity albeit 16-fold lower than $\mathbf{1}$. The poor solubility of $\mathbf{1}(<5 \mu \mathrm{M}$ at $\mathrm{pH} 7.4)$ may be explained by implicating intramolecular $\mathrm{H}$-bonding between the 2-pyridyl $\mathrm{N}$ and the $\mathrm{NH}$ of the methamine. By locking the 2-pyridylmethylamine in the same plane as the bicyclic ring system, this would result in the formation of a planar system capable of $\pi$-stacking to form an insoluble crystal lattice. Disruption of this molecular planarity by moving the $\mathrm{N}$ around the ring resulted in a significant increase in aqueous solubility $(110.2 \mu \mathrm{M}$ for 14 and $133.6 \mu \mathrm{M}$ for 15). Extension of the methamine tether by a two-carbon methylene spacer (18) or 3-carbon methylene space (19) led to a decrease in $M t b$ activity $\left(\mathrm{MIC}_{99}>160 \mu \mathrm{M}\right.$ and $80 \mu \mathrm{M}$ respectively). The calculated physicochemical properties of $\mathbf{1}$ confirm the trend in solubility with 1 being more lipophilic (clogP 4.09) than 14 and 15 (clogP 3.67). Removal of the methylene spacer to form compound $\mathbf{2 0}$ was detrimental to activity at the highest concentration tested. Also, methylation of the $\mathrm{NH}$ to $\mathrm{NMe}(\mathbf{2 1})$ resulted in a complete loss of activity. Similarly, replacing the arylmethyl amines with the corresponding ether analogue 22 was not tolerated. Replacement of the 2-pyridyl moiety with other heterocyclic systems such as imidazoles (24 and 25), methylpyridinyl (26), furan (27), thiophene (28), thiazole (29) and quinoline (30) generally resulted in a lack of antimycobacterial activity at the highest concentration tested $\left(\mathrm{MIC}_{99}>160 \mu \mathrm{M}\right)$. The exception was the methylimidazole analogue 23, which displayed good $\left(\mathrm{MIC}_{99}=5 \mu \mathrm{M}\right)$ activity. The imidazoles $(23$ and 25) did offer an improvement in kinetic solubility. Changes to the 7-position of the aminopyrazolo[1,5a]pyrimidine ring, which resulted in improved aqueous solubility, were not compatible with anti- $M t b$ activity and no compounds were identified with improved activity over the initial hit compound 1. This suggests that the pyridin-2-ylmethylmine substituent is important for the observed antimycobacterial activity.

Table 1. Antimycobacterial activity, aqueous solubility and clogP for 7-substituted aminopyrazolo[1,5-a]pyrimidines

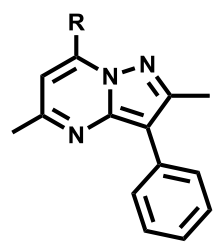

\begin{tabular}{ccccc}
\hline Compd & $\mathbf{R}$ & $\mathbf{M I C}_{99}(\mu \mathrm{M})^{a}$ & $\begin{array}{c}\text { Kinetic } \\
\text { Solubility } \\
(\mathbf{p H} 7.4)^{b}\end{array}$ & $\operatorname{clog}^{c}$ \\
\hline Rifampicin & 0.012 & & \\
Kanamycin & 6.45 & & \\
$\mathbf{1}$ & 5 & $<5$ & 4.09 \\
$\mathbf{1 4}$ & & $>160$ & 110.2 & 3.67
\end{tabular}

* Corresponding author. Tel.: +27 21 6502553; fax: +27 21 6505195; email: kelly.chibale@uct.ac.za 


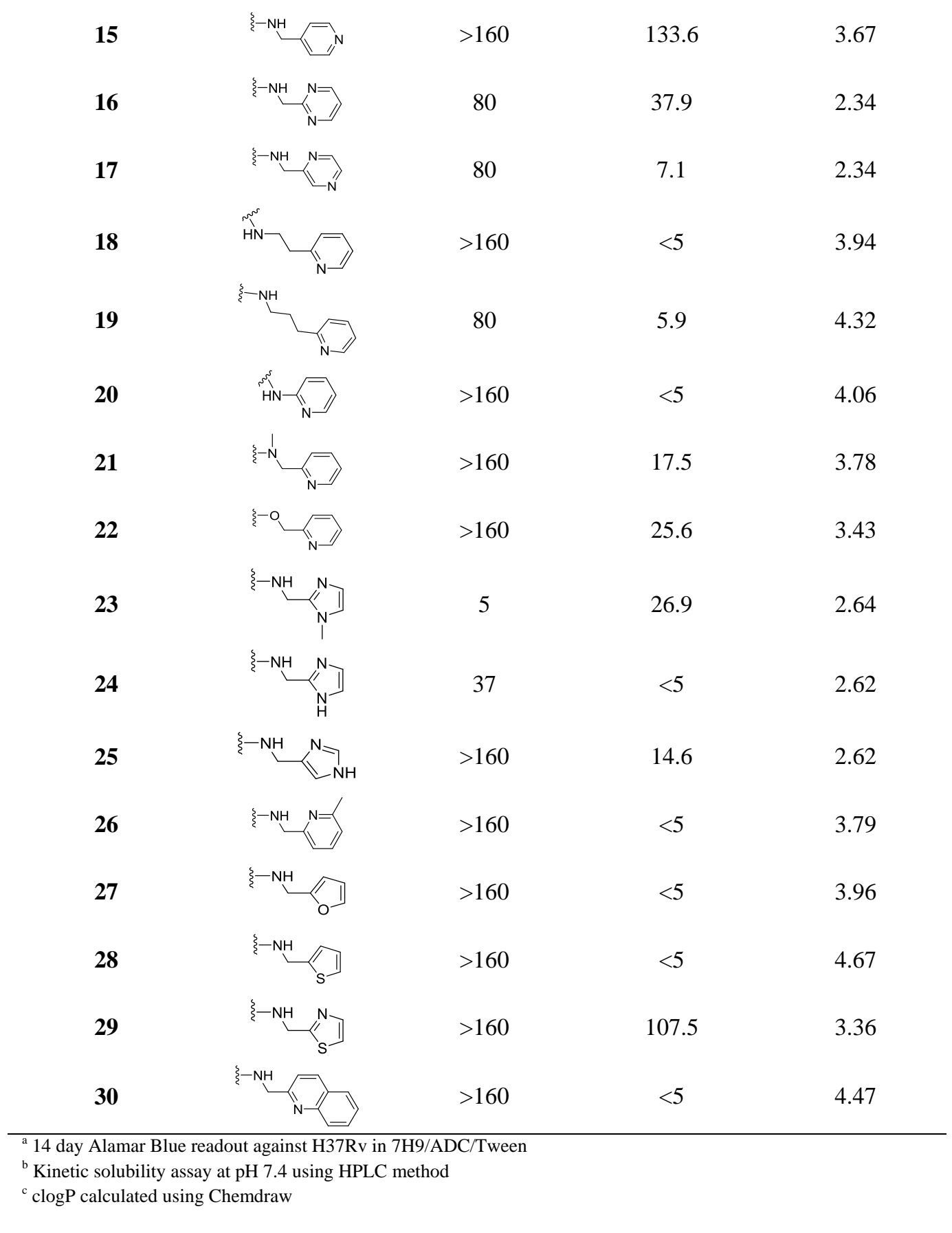

\subsection{Exploration of 3-position changes}

The first round of compounds to explore the 3-position of the pyrazolo[1,5-a]pyrimidine included examples with a methyl group in the 2-position of the scaffold or with no substituent at this position. This was envisaged to explore the effect of the methyl substituent on antimycobacterial activity. Table 2 summarizes the in vitro antimycobaterial activity and solubility data. The in vitro antimycobacterial activity for analogues where $\mathrm{R}_{1}=\mathrm{Me}$ or $\mathrm{H}(\mathbf{1}$, $\mathbf{2}, \mathbf{3}, \mathbf{4}, \mathbf{3 1}, \mathbf{3 2}$ ) are comparable and, for this reason, we decided to focus on the series lacking the $\mathrm{R}^{1}$ substituent in order to remove the potential metabolic liability of the methyl group. 
Table 2. Antimycobacterial activity and aqueous solubility for 3-substituted aminopyrazolo [1,5-a]pyrimidines

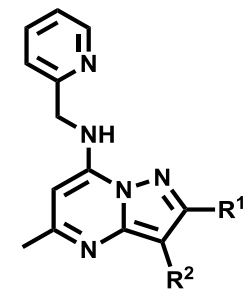

\begin{tabular}{|c|c|c|c|c|}
\hline Compd & $\mathbf{R}^{1}$ & $\mathbf{R}^{2}$ & $\operatorname{MIC}_{99}(\mu \mathrm{M})^{a}$ & 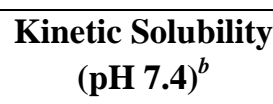 \\
\hline 2 & $\mathrm{H}$ & & 10 & $<5$ \\
\hline 3 & $\mathrm{CH}_{3}$ & & 5 & $<5$ \\
\hline 4 & $\mathrm{H}$ & & 5 & $<5$ \\
\hline 31 & $\mathrm{CH}_{3}$ & & 20 & $<5$ \\
\hline 32 & $\mathrm{H}$ & & 20 & $<5$ \\
\hline 5 & $\mathrm{H}$ & & 10 & $<5$ \\
\hline 6 & $\mathrm{H}$ & & 5 & $<5$ \\
\hline 33 & $\mathrm{H}$ & & 20 & $<5$ \\
\hline 34 & $\mathrm{H}$ & & $>160$ & $<5$ \\
\hline 35 & $\mathrm{H}$ & & $>160$ & $<5$ \\
\hline 36 & $\mathrm{H}$ & & 2.5 & $<5$ \\
\hline 37 & $\mathrm{H}$ & & 2.5 & 5 \\
\hline 38 & $\mathrm{H}$ & & 2.5 & 5 \\
\hline 39 & $\mathrm{H}$ & & 1.25 & $<5$ \\
\hline 40 & $\mathrm{H}$ & & 1.25 & $<5$ \\
\hline 41 & $\mathrm{H}$ & & $>160$ & $<5$ \\
\hline 42 & $\mathrm{H}$ & & $>160$ & $<5$ \\
\hline
\end{tabular}




43

A range of electron-withdrawing and electron-donating aromatic groups were prepared and tested for antimycobacterial activity. The data from alkyl, $O$ - and $N$-substituted phenyls 31, 32, 6 and 33 (see Table 2) suggests that an electron-rich phenyl substituent is beneficial for activity. On the other hand, electron-withdrawing halogenated phenyl analogues $(4,5,36,37$ and 38) displayed good activity against $M t b\left(\mathrm{MIC}_{99}=2.5-5 \mu \mathrm{M}\right.$, when $\left.\mathrm{R}_{1}=\mathrm{H}\right)$. It was observed that ortho and meta halogenated compounds $\left(36,37,38 ; \mathrm{MIC}_{99}=2.5 \mu \mathrm{M}\right)$ were 2to 4 -fold more potent than the corresponding para analogue $\left(\mathbf{3}, \mathbf{5} ; \mathrm{MIC}_{99}=5-10 \mu \mathrm{M}\right)$. The most potent compounds were the di-substituted 39 and $o$-tolyl 40 analogues which were equipotent $\left(\mathrm{MIC}_{99}=1.25 \mu \mathrm{M}\right)$. Di-substituted analogues 41 and 42, however, did not show comparable activity to $\mathbf{3 9}$. However, tri-fluoro analogue $\mathbf{4 3}$ displayed comparable activity to its meta- fluoro counterpart 37. Not surprisingly, there was no improvement in aqueous solubility with these compounds $(<5 \mu \mathrm{M})$. However, 5-ring heterocyclic variants $\mathbf{4 4 , 4 5}$ and 47 showed improved aqueous solubility albeit this was accompanied by a decrease in antimycobacterial activity. Furan analogue $44\left(\mathrm{MIC}_{99}=20 \mu \mathrm{M}\right)$ and thiophene analogue 45 $\left(\mathrm{MIC}_{99}=20 \mu \mathrm{M}\right)$ retained some activity. Replacement of the phenyl group with a pyridyl as in compound $\mathbf{4 6}$ or methylpyrazole 47 led to a complete loss of activity. Phenyl amide analogue (48) showed no activity at the highest concentration tested. Insertion of a $\mathrm{NH}$ group between the pyrazolopyridine core and the phenyl ring (49) resulted in a 32-fold reduction in activity compared to $\mathbf{1}$. The non-aromatic difluorocyclohexene compound $\mathbf{5 0}$ exhibited comparable activity to the fluorophenyl analogue (4) but did not offer an improvement in aqueous solubility despite the reduction in liphophilicity $(\mathbf{4} ; \operatorname{cog} \mathrm{P}=4.25$ and $\mathbf{5 0}$; $\operatorname{cog} \mathrm{P}=$ 
3.5). A dramatic increase in solubility was observed for dihydropyran analogue $\mathbf{5 1}$ but this compound displayed poor in vitro antimycobacterial activity. However, the bromo intermediate 12, without the Boc protecting group, is devoid of antimycobacterial activity. Interestingly when the $R^{2}$ substituent was removed entirely $\left(R^{2}=H\right.$, 52) the antimycobacterial activity was retained $\left(\mathrm{MIC}_{99}=5 \mu \mathrm{M}\right)$, and is comparable to the original hit compound 1 but with good solubility. This suggests that the $\mathrm{R}_{2}$ substituent is not essential for antimycobacterial activity in this series.

\subsection{In vitro ADME profiling}

In an attempt to address liabilities of poor solubility and metabolic stability, whilst maintaining potency, a further set of pyrazolo[1,5-a]pyrimidines were synthesised (Table 3). Strategies to improve aqueous solubility included introduction of hydrophilicity and removal of aromaticity and planarity ${ }^{31}$. A single time-point assay (\% compound remaining after $0.5 \mathrm{~h}$ ) was used to establish a ranking of compounds to predict half-life and this was measured in human, rat and mouse liver microsomes. Hit compound $\mathbf{1}$ exhibited poor metabolic stability in human liver microsomes (HLM $t_{1 / 2}=31.7 \mathrm{~min}$ ). It was hypothesized that the electron rich 2-pyridyl, methyl and phenyl groups of $\mathbf{1}$ are metabolic hot spots. The in vitro metabolic profiling of 1 resulted in formation of 3 hydroxylation metabolites in HLMs on the phenyl and 2-pyridyl ring systems. Therefore, we reasoned that blocking or modifying these groups should help to improve metabolic stability. Removal of aromaticity as for example with the piperidine (53) and pyrrolidine (54) analogues resulted in an improvement in kinetic solubility but with loss of antimycobacterial activity and no improvement in microsomal stability compared to $\mathbf{1}$. In order to potentially block metabolism, the metabolically labile 2pyridyl ring was replaced with a fluoro-substituted 2-pyridine ring to deliver compound $\mathbf{5 5}$, which retained activity against $M t b\left(\mathrm{MIC}_{99}=5 \mu \mathrm{M}\right)$. However, this compound exhibited similar metabolic stability issues in rat and mouse liver microsomes and reduced stability in human liver microsomes. The $\mathrm{N}$-oxide analogue (56) was synthesized to ascertain if the predicted metabolite would be active against $M t b$. No activity was seen with this derivative, suggesting that the basic pyridine $\mathrm{N}$ is important for activity. The promising antimycobacterial activity and improved solubility of $\mathbf{5 2}$ prompted the synthesis of compound 57 which resulted in a significant increase in aqueous solubility and metabolic stability but at the expense of antimycobacterial activity. Introduction of hydrophilicity by replacement of the $\mathrm{R}$ substituent with a triazole moiety $\mathbf{5 8}$ and $\mathrm{R}^{2}$ with polar phenyl substituents (59-62) all led to a marked improvement in solubility and metabolic stability, with the exception of the metabolically unstable $\mathrm{NMe}_{2}$ analogue 61. Unfortunately loss of potency was once again observed. A basic amine side chain (63) was also not tolerated. Ortho-substituted analogues 64 and 65 were synthesized to improve solubility by disruption of molecular planarity, which greatly improved the solubility of $\mathbf{6 5}$. However, $o$-fluoropyridyl 64 did not offer improved solubility but it was nevertheless metabolically stable and showed good antimycobacterial activity $\left(\mathrm{MIC}_{99}=10 \mu \mathrm{M}\right)$. It was unfortunate that any improvement in aqueous solubility led to simultaneous loss of in vitro antimycobacterial activity. This correlates with other series of TB compounds where increased hydrophobicity generally leads to higher Mtb activity. ${ }^{32}$ 
Table 3. Inhibition of $M t b$ Growth, kinetic solubility and in vitro Microsomal Metabolic Stability<smiles>[R]c1nn2c([R])cc(C)nc2c1[R]</smiles>

\begin{tabular}{|c|c|c|c|c|c|c|c|}
\hline Compd & $\mathbf{R}$ & $\mathbf{R}^{1}$ & $\mathbf{R}^{2}$ & $\begin{array}{l}\mathrm{MIC}_{99} \\
(\mu \mathrm{M})^{a}\end{array}$ & $\begin{array}{c}\text { Kinetic } \\
\text { Solubility } \\
(\mathrm{pH} 7.4)^{b}\end{array}$ & $\begin{array}{l}\text { Projected half life } \\
\qquad(\min ; \mathbf{h} / \mathbf{r} / \mathbf{m})^{c}\end{array}$ & $\begin{array}{c}\text { \% Remaining at } \\
30 \mathrm{~min}(\mathbf{h} / \mathbf{r} / \mathbf{m})^{d}\end{array}$ \\
\hline 1 & & $\mathrm{CH}_{3}$ & & 5 & $<5$ & $31.7 / 22.1 / 7.5$ & $51.9 / 39.0 / 6.2$ \\
\hline 53 & & $\mathrm{CH}_{3}$ & & $>160$ & 188.6 & $33.4 / 7.0 / 10.7$ & $51.8 / 5.1 / 14.0$ \\
\hline 54 & & $\mathrm{CH}_{3}$ & & $>160$ & 172 & $33.7 /-/-$ & 54.0/-/- \\
\hline 55 & & $\mathrm{CH}_{3}$ & & 5 & $<5$ & $18 / 26.4 / 7.1$ & $31.4 / 45.5 / 5.3$ \\
\hline 56 & & $\mathrm{H}$ & & $>160$ & 159 & $>100 / 42.3 / 9.9$ & $99.7 / 61.2 / 12.3$ \\
\hline 57 & & $\mathrm{CH}_{3}$ & $\mathrm{H}$ & $>160$ & 182.3 & $>100 / 96.9 />100$ & $100 / 80.6 / 85.1$ \\
\hline 58 & & $\mathrm{CH}_{3}$ & & $>160$ & 184.7 & $>100 / 55.7 / 12.5$ & $99.5 / 68.8 / 18.9$ \\
\hline 59 & & $\mathrm{H}$ & & $>160$ & 10.9 & $>100 / 41.0 / 23.6$ & $99.3 / 60.1 / 41.4$ \\
\hline 60 & & $\mathrm{H}$ & & $>160$ & 159.9 & $>100 / 36.7 / 35.1$ & $89.5 / 56.8 / 55.1$ \\
\hline 61 & & $\mathrm{H}$ & & 80 & 94.6 & 19.1/6.7/8.2 & $33.7 / 4.5 / 7.9$ \\
\hline 62 & & $\mathrm{H}$ & & 160 & 111 & - & - \\
\hline 63 & & $\mathrm{H}$ & & $>160$ & 189.3 & - & - \\
\hline 64 & & $\mathrm{CH}_{3}$ & & 10 & $<5$ & $>100 />100 />100$ & $100 / 96.5 / 100$ \\
\hline 65 & & $\mathrm{H}$ & & $>160$ & 42.3 & - & - \\
\hline
\end{tabular}

\subsection{Further Screening of Hit Compounds}

The most active compounds in the series were screened in GAST-Fe ${ }^{33}$ minimal media to confirm anti-Mtb activity in an additional growth media. We reasoned that this would allow insight into protein binding by comparison of the BSA-rich media (7H9) vs. non-BSA media

* Corresponding author. Tel.: +27 21 6502553; fax:+27 21 6505195; email: kelly.chibale@uct.ac.za 
(GAST-Fe), Fe-dependence (GAST-Fe vs. Low Fe GAST data) and provide supportive evidence that $M t b$ growth inhibition may be due to inhibition of a particular target or pathway. As shown in Table 4, all compounds were significantly less active in the GAST-Fe medium and activity of this series seems to be condition dependent. The compounds tested did not show iron dependence with comparison of the MIC in GAST-Fe and GAST without Fe displaying similar values with no impact on the already weak activity observed in this medium. In order to potentially identify the drug target or mechanism of action, whole-cell screening is coupled with whole-genome sequencing of resistant mutants. ${ }^{34}$ The leading compounds were evaluated for their activity on promiscuous targets ${ }^{35}$ including QcrB, a component of the respiratory $b c_{1}$ complex. The compounds showed no differential activity against the cyd mutant; moreover, given that all known QcrB inhibitors tested to date are more active in GAST/Fe medium, ${ }^{35 \mathrm{~b}}$ these data indicated that this compound series does not appear to be inhibiting this cell wall target. Additionally, a reporter assay for inhibition of targets involved in cell wall mycolyl-arabinogalactan biosynthesis ${ }^{36}$ indicated that these inhibitors were unlikely to affect promiscuous targets in cell wall biosynthesis ${ }^{35 a, 36}$ (results not shown). Efforts to determine the mechanism(s) of action are underway. In this regard, we will attempt to "de-construct" $7 \mathrm{H} 9$ to identify the components that are essential for the observed effect; in addition, we will continue to pursue the mutant generation work in order to identify a mechanism of resistance. The leading compounds and selected inactive compounds were tested for cytotoxicity against CHO cells. The SAR for cytotoxicity tracked that of the antibacterial activity with the active compounds displaying a narrow selectivity index, thus none of the leading compounds was progressed to in vivo studies.

Table 4. Variation of MIC values with growth media and cytotoxicity of leading compounds

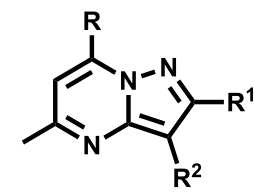

\begin{tabular}{|c|c|c|c|c|c|c|c|}
\hline Compd & $\mathbf{R}$ & $\mathbf{R}^{1}$ & $\mathbf{R}^{2}$ & $\begin{array}{c}\text { MIC }_{99} \\
\text { 7H9/ADC } \\
(\mu \mathrm{M})^{a} \\
\end{array}$ & $\begin{array}{c}\text { MIC }_{99} \\
\text { GAST-Fe } \\
(\mu \mathrm{M})^{b} \\
\end{array}$ & $\begin{array}{c}\text { MIC }_{99} \\
\text { Low Fe GAST } \\
(\mu \mathrm{M})^{c}\end{array}$ & $\begin{array}{r}\text { Cytotoxicity } \\
\mathrm{IC}_{50}(\mu \mathrm{M})^{d}\end{array}$ \\
\hline 1 & & $\mathrm{CH}_{3}$ & & 5 & $>160$ & $>160$ & 34 \\
\hline 23 & & $\mathrm{CH}_{3}$ & & 5 & 37 & 20 & $<9.0$ \\
\hline 36 & & $\mathrm{H}$ & & 2.5 & $>160$ & $>160$ & 3.78 \\
\hline 38 & & $\mathrm{H}$ & & 2.5 & $>160$ & $>160$ & 5.45 \\
\hline 39 & & $\mathrm{H}$ & & 1.25 & $>160$ & $>160$ & 19.98 \\
\hline 55 & & $\mathrm{CH}_{3}$ & & 5 & 20 & $>160$ & 22 \\
\hline
\end{tabular}

${ }^{a} 14$ day Alamar Blue readout against $\mathrm{H} 37 \mathrm{Rv}$ in $7 \mathrm{H} 9 / \mathrm{ADC} / \mathrm{Tween}$

${ }^{b} 14$ day Alamar Blue readout against H37Rv in GAST-Fe

* Corresponding author. Tel.: +27 21 6502553; fax: +27 21 6505195; email: kelly.chibale@uct.ac.za 
${ }^{b} 14$ day Alamar Blue readout against H37Rv in low Fe GAST

${ }^{d}$ Cytotoxicity against Chinese Hamster Ovarian cells (CHO)

\section{Conclusion}

In conclusion, a novel series of pyrazolo[1,5-a]pyrimidines with promising in vitro antimycobacterial activity has been identified from a whole-cell high-throughput screening campaign. Medicinal chemistry efforts focused on exploration of the $\mathrm{R}$ substituent at position 7 and the $\mathrm{R}^{2}$ substituent at position 3 to identify a number of promising hit compounds $\mathbf{1}, \mathbf{2 3}$, 36, 38 and 39 displaying a $\mathrm{MIC}_{99}$ values of $1.25-5 \mu \mathrm{M}$ in $7 \mathrm{H} 9$ media. The series displays SAR trends, and key substituents important for antimycobacterial activity have been identified to inform a future optimisation campaign. However, this series suffers from the liabilities of poor aqueous solubility and in vitro cytotoxicity, both of which will need to be addressed without compromising in vitro antimycobacterial activity in any future optimisation campaign.

\section{Experimental section}

\subsection{Chemistry}

\subsubsection{General}

All reagents and solvents were obtained from commercial sources and used as received. All dry solvents were obtained from an SP-1 standalone solvent purification system from LC Technology Solutions Inc. Reactions were monitored by thin layer chromatography (TLC) using Merck TLC silica gel $60 \mathrm{~F}_{254}$ aluminium-backed precoated plates and were visualized by ultraviolet light at $254 \mathrm{~nm}$. Purification of compounds was carried out by either column chromatography on silica gel 60 (Fluka), particle size 0.063-0.2 mm (70-230 mesh ASTM), as the stationary phase, or by Waters' HPLC using X-bridge C18 $5 \mu \mathrm{m}$ column $(4.6 \mathrm{x} 150$ $\mathrm{mm}$ ); organic phase: $10 \mathrm{mM}$ Ammonium acetate (pH 3.7) in HPLC grade methanol, aqueous phase: $10 \mathrm{mM}$ Ammonium acetate $(\mathrm{pH} 3.7)$ in HPLC grade water; flow rate $=15.00 \mathrm{~mL} / \mathrm{min}$; detector: photodiode array (PDA). All target compounds and intermediates were characterised by ${ }^{1} \mathrm{HNMR},{ }^{13} \mathrm{CNMR}$ and MS. NMR spectra were recorded on either a Varian Mercury-300 $\left({ }^{1} \mathrm{H} 300.1 \mathrm{MHz},{ }^{13} \mathrm{C} 75.5 \mathrm{MHz}\right)$ or Bruker-400 $\left({ }^{1} \mathrm{H} 400.2 \mathrm{MHz},{ }^{13} \mathrm{C} 100.6 \mathrm{MHz}\right)$ instrument using $\mathrm{CDCl}_{3}, \mathrm{MeOH}-d_{4}$ and DMSO- $d_{6}$ as solvents. The ${ }^{1} \mathrm{H}$ NMR data are reported as follows: chemical shift in parts per million $(\delta)$ downfield of tetramethylsilane (TMS), multiplicity ( $\mathrm{s}=$ singlet, $\mathrm{bs}=$ broad singlet, $\mathrm{d}=$ doublet, $\mathrm{t}=$ triplet, $\mathrm{q}=$ quartet, $\mathrm{dd}$ $=$ doublets of doublets, $\mathrm{dt}=$ triplets of doublets and $\mathrm{m}=$ multiplet $)$, coupling constant $(\mathrm{Hz})$, and integrated value. The ${ }^{13} \mathrm{C}$ NMR spectra were measured with complete proton decoupling. LC-MS/MS analysis was performed using an Agilent ${ }^{\circledR} 1260$ Infinity Binary Pump, Agilent ${ }^{\circledR}$ 1260 Infinity Diode Array Detector (DAD), Agilent ${ }^{\circledR} 1290$ Infinity Column Compartment, Agilent ${ }^{\circledR} 1260$ Infinity Standard Autosampler, and a Agilent ${ }^{\circledR} 6120$ Quadrupole (Single) MS, with APCI/ESI multimode ionisation source. The purities were determined by Agilent ${ }^{\circledR}$ LCMS/MS or Waters' HPLC using X-bridge C18 $5 \mu \mathrm{m}$ column (4.6 x $150 \mathrm{~mm}$ ); organic phase: $10 \mathrm{mM}$ Ammonium acetate ( $\mathrm{pH}$ 3.7) in HPLC grade methanol, aqueous phase: $10 \mathrm{mM}$ 
Ammonium acetate $(\mathrm{pH} 3.7)$ in HPLC grade water; flow rate $=1.20 \mathrm{~mL} / \mathrm{min}$; detector: photodiode array (PDA). The purities of all compounds were found to be $>95 \%$.

\subsubsection{Scaffold Synthesis}

\section{Synthesis of 2,5-dimethyl-3-phenylpyrazolo[1,5-a]pyrimidin-7(4H)-one (7)}

Ethyl acetoacetate $(7.6 \mathrm{ml}, 60.3 \mathrm{mmol})$ was added dropwise to a stirred solution of 3-methyl4-phenyl-1H-pyrazol-5-amine $(10.0 \mathrm{~g}, 54.8 \mathrm{mmol})$ in acetic acid $(50 \mathrm{ml})$ and refluxed at $120^{\circ} \mathrm{C}$ for $16 \mathrm{hrs}$. The reaction mixture was cooled and poured into cooled TBME $(300 \mathrm{ml})$ and stirred at $0^{\circ} \mathrm{C}$ for $1 \mathrm{~h}$. The resulting precipitate was filtered, washed with TBME $(100 \mathrm{ml})$ and dried at $70^{\circ} \mathrm{C}$ to obtain a cream solid (quantitative, $14.45 \mathrm{~g}, 60.3 \mathrm{mmol}$ ). $\delta_{\mathrm{H}}(400 \mathrm{MHz}$; $\left.\mathrm{CDCl}_{3}\right) 11.72(\mathrm{br} \mathrm{s}, 1 \mathrm{H}), 7.48-7.35(\mathrm{~m}, 5 \mathrm{H}), 5.55(\mathrm{~s}, 1 \mathrm{H}), 2.26(\mathrm{~s}, 3 \mathrm{H}), 2.25(\mathrm{~s}, 3 \mathrm{H}) ; \delta_{\mathrm{C}}(101$ $\mathrm{MHz} ; \mathrm{CDCl}_{3}$ ) 156.3, 151.1, 150.2, 139.2, 131.3, 129.9 (x2), 129.2 (x2), 127.3, 103.3, 96.1, 19.1, 13.5. LCMS (ESI): $m / z 240[\mathrm{M}+\mathrm{H}]^{+}$; HPLC purity $97 \%$.

\subsubsection{Intermediate Synthesis}

\section{Synthesis of 7-chloro-2,5-dimethyl-3-phenylpyrazolo[1,5-a]pyrimidine (8)}

Phosphoryl trichloride $(5.7 \mathrm{ml}, 62.7 \mathrm{mmol})$ and $N, N$-dimethylaniline $(3.3 \mathrm{ml}, 26.1 \mathrm{mmol})$ were added dropwise to a stirred solution of [2,5-dimethyl-3-phenylpyrazolo[1,5a]pyrimidin-7(4H)-one $(7)(5.00 \mathrm{~g}, 20.9 \mathrm{mmol})$ in toluene $(50 \mathrm{ml})$, and refluxed at $120^{\circ} \mathrm{C}$. After $2.5 \mathrm{~h}$, the reaction mixture was allowed to cool and was concentrated. The black residue was poured into a beaker containing crushed ice $(100 \mathrm{~mL})$ and the resulting solution was neutralised with $\mathrm{NaHCO}_{3}$. The aqueous solution was extracted with EtOAc $(3 \times 150 \mathrm{~mL})$ and the combined organic phase was washed with brine $(100 \mathrm{~mL})$. The organic phase was dried over $\mathrm{Na}_{2} \mathrm{SO}_{4}$ and concentrated to yield the desired crude product which was purified by column chromatography (10\% EtOAC/hexane) to obtain a light green powder (Yield $=96 \%$, $5.16 \mathrm{~g}, 20.02 \mathrm{mmol}) . \delta_{\mathrm{H}}\left(400 \mathrm{MHz} ; \mathrm{CDCl}_{3}\right) 7.31-7.17(\mathrm{~m}, 5 \mathrm{H}), 6.80(\mathrm{~s}, 1 \mathrm{H}), 2.71(\mathrm{~s}, 3 \mathrm{H})$, $2.61(\mathrm{~S}, 3 \mathrm{H})$; LCMS (ESI): $m / z 260[\mathrm{M}+\mathrm{H}]^{+}$; HPLC purity $95 \%$.

\subsubsection{Library Production}

\section{General procedure A for synthesis of 7-substituted aminopyrazolo[1,5-a]pyrimidines (9)}

To a solution of 7-chloro-2,5-dimethyl-3-phenylpyrazolo[1,5-a]pyrimidine (1 equiv) and diisopropylethylamine (1.5 equiv) in 2-propanol was added amine (1.2 equiv). After refluxing for $16 \mathrm{~h}$, the reaction mixture was concentrated in vacuo and the appropriate solvent added to precipitate the crude product, which was collected by filtration and then purified by recrystallization, prep HPLC or column chromatography.

\subsubsection{Synthesis of 2,5-dimethyl-3-phenyl- $N$-(pyridin-3-ylmethyl)pyrazolo[1,5- a]pyrimidin-7-amine (14)}

A representative experimental for General Procedure A. Characterization data of 15-30 is provided in the Supplementary data. The title compound was synthesized from 8 (100 mg,

* Corresponding author. Tel.: +27 21 6502553; fax:+27 21 6505195; email: kelly.chibale@uct.ac.za 
$0.388 \mathrm{mmol})$ using general procedure A to afford $(127 \mathrm{mg}, 98 \%)$ of a yellow coloured powder recrystallized from DCM/hexane. $\delta_{\mathrm{H}}\left(400 \mathrm{MHz}\right.$; DMSO- $\left.d_{6}\right) 8.68(\mathrm{~d}, J=4.0 \mathrm{~Hz}, 1 \mathrm{H})$, $8.49(\mathrm{dd}, J=8.0$ and $4.0 \mathrm{~Hz}, 1 \mathrm{H}), 8.27(\mathrm{t}, J=8.0 \mathrm{~Hz}, 1 \mathrm{H}), 7.82(\mathrm{dt}, \mathrm{J}=8.0,4.0$ and $1.6 \mathrm{~Hz}$, $1 \mathrm{H}), 7.74(\mathrm{dd}, J=8.0$ and $4.0 \mathrm{~Hz}, 2 \mathrm{H}), 7.42(\mathrm{~m}, 2 \mathrm{H}), 7.36(\mathrm{ddd}, J=8.0,4.0$ and $1.6 \mathrm{~Hz}, 1 \mathrm{H})$, $7.23(\mathrm{~m}, 1 \mathrm{H}), 6.09(\mathrm{~s}, 1 \mathrm{H}), 4.68(\mathrm{~d}, J=8.0 \mathrm{~Hz}, 1 \mathrm{H}), 2.56(\mathrm{~s}, 3 \mathrm{H}), 2.37(\mathrm{~s}, 3 \mathrm{H}) . \delta_{\mathrm{C}}(101 \mathrm{MHz}$; DMSO- $\left.d_{6}\right) 206.3,159.4,150.6,149.2,148.9,145.6,145.3,135.4,134.3,133.8,128.7,128.5$, 125.6, 123.9, 106.2, 85.2, 42.8, 31.0, 25.2, 14.8. LCMS (ESI): $m / z 330.1[\mathrm{M}+\mathrm{H}]^{+}$; HPLC purity $96 \%$.

\subsubsection{Scaffold Synthesis}

General procedure for the synthesis of 7-chloro-5-methylpyrazolo[1,5-a]pyrimidine (10a) and 7-chloro-5-methylpyrazolo[1,5-a]pyridimidine (10b)

Methyl acetoacetate (1.1 equiv) or ethyl acetoacetate (1.1 equiv) was added dropwise to a stirred solution of 3-amino- $1 H$-pyrazole ( 1 equiv) or 3 -amino-5-methyl- $1 H$-pyrazole ( 1 equiv) in acetic acid and refluxed at $120^{\circ} \mathrm{C}$ for $16 \mathrm{hrs}$. The reaction mixture was cooled and poured into cooled TBME and stirred at $0^{\circ} \mathrm{C}$ for $1 \mathrm{~h}$. The resulting precipitate was filtered, washed with TBME and dried at $70^{\circ} \mathrm{C}$ to obtain a cream solid. $\mathbf{a} \mathrm{R}=\mathrm{H}$, (Yield $=87 \%, 18.35$ g, $123.13 \mathrm{mmol}) . \delta_{\mathrm{H}}\left(400 \mathrm{MHz} ; \mathrm{CDCl}_{3}\right) 12.22$ (br s, $\left.1 \mathrm{H}\right), 7.79(\mathrm{dd}, J=2.0$ and $0.8 \mathrm{~Hz}, 1 \mathrm{H})$, $6.06(\mathrm{dd}, J=2.0$ and $0.8 \mathrm{~Hz}, 1 \mathrm{H}), 5.54(\mathrm{~s}, 1 \mathrm{H}), 2.27(\mathrm{~m}, 3 \mathrm{H}) . \mathbf{b} \mathrm{R}=\mathrm{Me}$, (Yield = 82 \%, 16.68 g, $101.87 \mathrm{mmol}) . \delta_{\mathrm{H}}\left(400 \mathrm{MHz}\right.$; DMSO- $\left.d_{6}\right) 12.01$ (bs, 1H), 5.90 (d, $\left.J=0.4 \mathrm{~Hz}, 1 \mathrm{H}\right), 5.49$ (d, $J=0.8 \mathrm{~Hz}, 1 \mathrm{H}), 2.27(\mathrm{~d}, J=0.4 \mathrm{~Hz}, 3 \mathrm{H}), 2.26(\mathrm{~d}, J=0.4 \mathrm{~Hz}, 3 \mathrm{H})$.

$\mathrm{N}, \mathrm{N}$-Dimethylaniline (1.25 equiv) was added to a stirred solution of 5-methylpyrazolo[1,5a]pyrimidin-7(4H)-one (a) or 2,5-dimethylpyrazolo[1,5-a]pyrimidin-7(4H)-one (b) (1 equiv) in toluene, followed by the addition of phosphorus oxychloride ( 3 equiv). The reaction mixture was heated at reflux for $4 \mathrm{~h}$. The reaction mixture was allowed to cool and was neutralised with $\mathrm{NaOH}(2 \mathrm{M})$. The aqueous solution was extracted with DCM $(3 \times)$ and the combined organic phase was washed with brine. The organic phase was dried, concentrated and the crude product was purified by column chromatography (10\% EtOAc/hexane) to yield the desired light yellow solid 10a Yield $=41 \%$. $\delta_{\mathrm{H}}\left(400 \mathrm{MHz} ; \mathrm{CDCl}_{3}\right) 8.15(\mathrm{~d}, J=2.4 \mathrm{~Hz}$, $1 \mathrm{H}), 6.83(\mathrm{~s}, 1 \mathrm{H}), 6.65(\mathrm{~d}, J=2.4 \mathrm{~Hz}, 1 \mathrm{H}), 2.59$ (s, 3H). MS: m/z $168[\mathrm{M}]^{+} \mathbf{1 0 b}$ Yield = 46 $\%$. $\delta_{\mathrm{H}}\left(400 \mathrm{MHz} ; \mathrm{CDCl}_{3}\right) 6.74(\mathrm{~s}, 1 \mathrm{H}), 6.43(\mathrm{~s}, 1 \mathrm{H}), 2.56$ (s, 3H), 2.54 (s, 3H). LCMS (ESI): $m / z, 182[\mathrm{M}+\mathrm{H}]^{+}$

\subsubsection{General procedure for the synthesis of 3-bromo-7-chloro-5-methylpyrazolo (11a) and 3-bromo-7-chloro-2,5-dimethylpyrazolo[1,5-a]pyrimidine (11b)}

A solution of 10a or $10 \mathbf{b}$ ( 1 equiv) in dichloromethane was cooled to $0{ }^{\circ} \mathrm{C}$ using an ice bath. $\mathrm{N}$-bromosuccinimide (1.1 equiv) was added slowly to the solution that was stirred for $16 \mathrm{~h}$ at room temperature. The reaction mixture was washed diluted with water and the reaction micture extracted with dichloromethane $(3 \mathrm{x})$. The organic phase was dried over $\mathrm{Na}_{2} \mathrm{SO}_{4}$ and concentrated to yield the desired product as a yellow solid. 11a Yield $=$ quantitative. $\delta_{\mathrm{H}}(400$ $\left.\mathrm{MHz} ; \mathrm{CDCl}_{3}\right) 8.13$ (s, 1H), $6.88(\mathrm{~s}, 1 \mathrm{H}), 2.63$ (s, 3H). LCMS (ESI): $m / z, 247[\mathrm{M}+\mathrm{H}]^{+} \mathbf{1 1 b}$ 
Yield $=$ quantitative $\delta_{\mathrm{H}}\left(400 \mathrm{MHz} ; \mathrm{CDCl}_{3}\right) 8.13(\mathrm{~s}, 1 \mathrm{H}), 2.85(\mathrm{~s}, 3 \mathrm{H}), 2.63(\mathrm{~s}, 3 \mathrm{H}) . \mathrm{LCMS}$ (ESI): $m / z, 261[\mathrm{M}+\mathrm{H}]^{+}$

\subsubsection{Intermediate synthesis}

General procedure for the synthesis of tert-butyl (3-bromo-5-methylpyrazolo[1,5a]pyrimidin-7-yl)(pyridin-2-ylmethyl)carbamate (12a) and tert-butyl (3-bromo-2,5dimethylpyrazolo[1,5-a]pyrimidin-7-yl)(pyridin-2-ylmethyl)carbamate (12b)

To a solution of 11a or 11b (1 equiv) and diisopropylethylamine (1.5 equiv) in 2-propanol was added pyridin-2-ylmethanamine (1.2 equiv). After heating for $16 \mathrm{~h}$ at $80{ }^{\circ} \mathrm{C}$, the precipitate that formed was collected by filtration. The product was washed with water and $2-$ propanol and dried to yield the product as a white solid, which was sufficiently pure to be used in the next step. Di-tert-butyl dicarbonate (1.5 equiv) was added to a stirred solution of the free amine ( 1 equiv) in dichloromethane, followed by the addition of dimethylaminopyridine ( 0.1 equiv), and diisopropylamine ( 1.5 equiv). After stirring for $24 \mathrm{~h}$, the reaction mixture was concentrated and partitioned between EtOAc and water. After separation, the organic phase was washed with $10 \%$ citric acid and brine, dried and concentrated. The crude product was purified by column chromatography.12a Yield $=78 \%$ over two steps. $\delta_{\mathrm{H}}\left(400 \mathrm{MHz}\right.$; DMSO- $\left.d_{6}\right) 8.58(\mathrm{~d}, J=4.0 \mathrm{~Hz}, 1 \mathrm{H}), 8.0(\mathrm{~s}, 1 \mathrm{H}), 7.73(\mathrm{td}, J=$ 8.0 and $4.0 \mathrm{~Hz}, 1 \mathrm{H}), 7.32(\mathrm{~d}, J=8.0 \mathrm{~Hz}, 1 \mathrm{H}), 7.28(\mathrm{t}, J=8.0,1 \mathrm{H}), 5.91(\mathrm{~s}, 1 \mathrm{H}), 4.7(\mathrm{~s}, 2 \mathrm{H})$, $2.57(\mathrm{~s}, 3 \mathrm{H}), 1.30(\mathrm{~s}, 9 \mathrm{H}) . \mathbf{1 2 b}$ Yield $=75 \% \delta_{\mathrm{H}}\left(400 \mathrm{MHz}\right.$; DMSO- $\left.d_{6}\right) 8.58(\mathrm{~d}, J=8.0 \mathrm{~Hz}$, $1 \mathrm{H}), 7.73(\mathrm{td}, J=8.0$ and $2.0 \mathrm{~Hz}, 1 \mathrm{H}), 7.32(\mathrm{~d}, J=8.0 \mathrm{~Hz}, 1 \mathrm{H}), 7.28(\mathrm{t}, J=8.0,1 \mathrm{H}), 5.91$ (s, $1 \mathrm{H}), 4.7$ (s, 2H), 2.87 (s, 3H), 2.57 (s, 3H), 1.30 (s, 9H).

\subsubsection{Library production}

General procedure $B$ for synthesis of 3-substituted aminopyrazolo[1,5-a]pyrimidines (13)

To a solution of 12 (1 equiv) in dioxane and water (5:1) was added boronic acid (1.2 equiv) followed by addition of cesium carbonate ( 1 equiv) and $\mathrm{PdCl}_{2}(\mathrm{dffp})(0.1$ equiv). The reaction mixture was degassed and heated at $80{ }^{\circ} \mathrm{C}$ overnight. The reaction was diluted with EtOAc and washed with water $(2 \mathrm{x})$. After drying over $\mathrm{Na}_{2} \mathrm{SO}_{4}$, filtration and concentration, the crude product was dissolved in DCM $(4 \mathrm{ml})$ and TFA $(8 \mathrm{ml})$ was added. The reaction was stirred for $4 \mathrm{hrs}$ at $\mathrm{rt}$ followed by concentration. The residue was dissolved in DCM and washed with $10 \% \mathrm{Na}_{2} \mathrm{CO}_{3}(2 \mathrm{x})$, the organic layer was dried $\left(\mathrm{MgSO}_{4}\right)$, filtered and concentrated. The crude product was purified by flash column chromatography $(80 \%$ EtOAc/Hex) or recrystallization from DCM/Hexane or by prep TLC (EtOAc) to give the desired product.

\subsubsection{Synthesis of 2,5-dimethyl-3-phenyl- $N$-(pyridin-2-ylmethyl)pyrazolo[1,5- a]pyrimidin-7-amine (1)}

A representative experimental for General Procedure B. Characterization data of 2-6 and 31$\mathbf{5 2}$ is provided in the Supplementary data. The title compound was synthesized from $\mathbf{1 2 b}$ (400

\footnotetext{
* Corresponding author. Tel.: +27 21 6502553; fax: +27 21 6505195; email: kelly.chibale@uct.ac.za
} 
$\mathrm{mg}, 0.925 \mathrm{mmol})$ using general procedure B to afford (84 $\mathrm{mg}, 27 \%)$ as an off white solid after purification by flash column chromatography $(80 \% \mathrm{EtOAc} / \mathrm{Hex})$ followed by recrystallization from DCM/Hexane and finally by prep TLC (EtOAc). $\delta_{\mathrm{H}}(400 \mathrm{MHz}$; DMSO- $\left.d_{6}\right) 8.68(\mathrm{ddd}, J=4.0,1.6$ and $0.8 \mathrm{~Hz}, 1 \mathrm{H}), 7.78-7.71(\mathrm{~m}, 3 \mathrm{H}), 7.45(\mathrm{t}, J=8.0 \mathrm{~Hz}$, 2H), $7.38(\mathrm{~d}, J=8.0 \mathrm{~Hz}, 1 \mathrm{H}), 7.30-7.26(\mathrm{~m}, 2 \mathrm{H}), 5.86(\mathrm{~s}, 1 \mathrm{H}), 4.75(\mathrm{~d}, J=8.0 \mathrm{~Hz}, 2 \mathrm{H}), 2.63$ $(\mathrm{s}, 3 \mathrm{H}), 2.53(\mathrm{~s}, 3 \mathrm{H}) . \delta_{\mathrm{C}}\left(101 \mathrm{MHz} ; \mathrm{CDCl}_{3}\right) 159.5,155.5,151.5,149.6,145.9,145.8,137.0$, 133.0, 128.8 (x2), 128.4 (x2), 125.8, 122.8, 121.2, 107.5, 85.9, 46.9, 25.2, 14.4. LCMS (ESI): $\mathrm{m} / \mathrm{z} 330.1[\mathrm{M}+\mathrm{H}]^{+}$; HPLC purity $96.3 \%$.

\subsection{M. tuberculosis H37Rv Minimum Inhibitory Concentration (MIC) assays}

The broth microdilution method ${ }^{27}$ allows a range of antibiotic concentrations to be tested on a single 96-well microtitre plate in order to determine the minimum inhibitory concentration (MIC). MICs were determined according to the broth microdilution method in liquid $7 \mathrm{H} 9$ medium supplemented with ADC (bovine albumin fraction $\mathrm{V}[5 \mathrm{mg} / \mathrm{ml}$, D-Glucose $[2 \mathrm{mg} / \mathrm{ml}]$, sodium chloride $[0.81 \mathrm{mg} / \mathrm{ml}]$ ) and/or in the glycerol-alanine-salts (GAST-Fe) medium pH 6.6, supplemented with [per liter: $0.3 \mathrm{~g}$ of Bacto Casitone (Difco), $0.05 \mathrm{~g}$ of ferric ammonium citrate, $4.0 \mathrm{~g}$ of dibasic potassium phosphate, $2.0 \mathrm{~g}$ of citric acid, $1.0 \mathrm{~g}$ of Lalanine, $1.2 \mathrm{~g}$ of magnesium chloride hexahydrate, $0.6 \mathrm{~g}$ of potassium sulfate, $2.0 \mathrm{~g}$ of ammonium chloride, $1.80 \mathrm{ml}$ of $10 \mathrm{~g}$ sodium hydroxide, and $10.0 \mathrm{ml}$ of glycerol, Tween 80 was added to $0.05 \%] .{ }^{33}$ Low iron GAST medium is normal GAST medium but without the ferric ammonium citrate.

Briefly, a $10 \mathrm{ml}$ culture of Mycobacterium tuberculosis $(\mathrm{Ma})^{38}$ is grown to an $\mathrm{OD}_{600}$ of 0.6 0.7. The culture is then diluted with 1:500 in liquid $7 \mathrm{H} 9$ or diluted 1:100 in BSA-free GAST/Fe medium. In a 96-well microtitre plate, $50 \mu \mathrm{l}$ of medium is added to all wells from Rows 2-12. The compounds to be tested are added to Row 1 in duplicate, at a final concentration of $640 \mu \mathrm{M}$ (stocks are made up to a concentration of $12.8 \mathrm{mM}$ in DMSO, and diluted to $640 \mu \mathrm{M}$ in medium). A two-fold serial dilution is prepared, using a multichannel pipette, by transferring $50 \mu \mathrm{l}$ of the liquid in Row 1 to Row 2 and aspirating to mix. $50 \mu 1$ of the liquid in Row 2 is then transferred to Row 3 and aspirated, and so on. This procedure is repeated until Row 12 is reached, from which $50 \mu 1$ of the liquid is discarded so as to bring the final volume in all wells to $50 \mu$ l. Controls include media only, 5\% DMSO, Rifampicin and Kanamycin. Finally, $50 \mu \mathrm{l}$ of the diluted M. tuberculosis culture (1:500 for $7 \mathrm{H} 9$ or 1:100 for GAST-Fe) is added to all wells in Rows 2-12. Cells are not added to Row 1, as this serves as a contamination control. The microtitre plate is sealed in a ziplock bag and incubated at $37^{\circ} \mathrm{C}$ with humidifier to prevent evaporation of liquid. The lowest concentration of drug that inhibits growth of more than $99 \%$ of the bacterial population is considered to be the $\mathrm{MIC}_{99}$. $\mathrm{MIC}_{99}$ values are scored visually at 7-days and 14-days post inoculation, and digital images captured and stored.

\subsection{Kinetic solubility assay}

The kinetic solubility assay was performed using a miniaturised shake flask method. ${ }^{39} 10 \mathrm{mM}$ stock solutions of each of the test compounds were used to prepare calibration standards (10-

* Corresponding author. Tel.: +27 21 6502553; fax: +27 21 6505195; email: kelly.chibale@uct.ac.za 
$220 \mu \mathrm{M})$ in DMSO, and to spike (1:50) duplicate aqueous samples of phosphate buffered saline ( $\mathrm{pH}$ 6.5), 0.01M HCL ( $\mathrm{pH}$ 2) and FaSSIF (simulating fasting state biorelevant media, $\mathrm{pH}$ 6.5), with a final DMSO concentration of $2 \%$. After shaking for 2 hours at $25^{\circ} \mathrm{C}$, the solutions were filtered and analysed by means of HPLC-DAD (Agilent 1200 Rapid Resolution HPLC with a diode array detector). Best fit calibration curves were constructed using the calibration standards, which were used to determine the aqueous samples' solubility.

\subsection{Metabolic stability assay}

The metabolic stability assay was performed in duplicate in a 96-well micro titre plate. The test compounds $(0.1 \mu \mathrm{M})$ were incubated individually in mouse, rat and pooled human liver microsomes $(0.4 \mathrm{mg} / \mathrm{ml})$ at $37{ }^{\circ} \mathrm{C}$ for predetermined times, in the presence and absence of the cofactor NADPH $(1 \mathrm{mM})$. Reactions were quenched by adding $300 \mu \mathrm{l}$ of ice cold acetonitrile containing internal standard (carbamazepine, $0.0236 \mu \mathrm{g} / \mathrm{mL}$ ). Test compounds in the supernatant were quantified by means of specific LC-MS/MS (Agilent Rapid Resolution HPLC, AB SCIEX 4000 QTRAP MS) methods. Metabolite searches were not conducted during the metabolic stability assay. ${ }^{40}$

\subsection{Chinese hamster ovarian (CHO) Cytotoxicity assay}

Test samples were screened for in vitro cytotoxicity against a mammalian cell-line, Chinese Hamster Ovarian (CHO) using the 3-(4,5-dimethylthiazol-2-yl)-2,5-diphenyltetrazolium bromide (MTT)-assay. The MTT-assay is used as a colorimetric assay for cellular growth and survival, and compares well with other available assays. ${ }^{41,42}$ The tetrazolium salt MTT was used to measure all growth and chemosensitivity. The tetrazolium ring is cleaved in active mitochondria. Thus only viable cells are able to reduce the water-soluble yellow coloured MTT to water-insoluble purple coloured formazan. Formazan crystals are dissolved in dimethyl sulphoxide (DMSO).The test samples were tested in triplicate on one occasion. The test samples were prepared to a $20 \mathrm{mg} / \mathrm{ml}$ stock solution in $100 \%$ DMSO. Stock solutions were stored at $-20^{\circ} \mathrm{C}$. Further dilutions were prepared in complete medium on the day of the experiment. Samples were tested as a suspension if not completely dissolved. Emetine was used as the reference drug in all experiments. The initial concentration of emetine was 100 $\mu \mathrm{g} / \mathrm{ml}$, which was serially diluted in complete medium with 10 -fold dilutions to give 6 concentrations, the lowest being $0.001 \mu \mathrm{g} / \mathrm{ml}$. The same dilution technique was applied to the all test samples. The highest concentration of solvent to which the cells were exposed to had no measurable effect on the cell viability (data not shown). The 50\% inhibitory concentration $\left(\mathrm{IC}_{50}\right)$ values were obtained from full dose-response curves, using a non-linear dose-response curve fitting analysis via GraphPad Prism v.4 software.

\section{Acknowledgements}

This work was funded, in part, by the Intramural Research Program of NIAID, by grants from the Foundation for the National Institutes of Health with support from the Bill \& Melinda Gates Foundation, and by the South African Medical Research Council (MRC), the South African Tuberculosis Research and Innovation Initiative (SATRII) and the Strategic Health

\footnotetext{
* Corresponding author. Tel.: +27 21 6502553; fax: +27 21 6505195; email: kelly.chibale@uct.ac.za
} 
and Innovation partnership (SHIP). The University of Cape Town, South African Medical Research Council, and South African Research Chairs Initiative of the Department of Science and Technology, administered through the South African National Research Foundation are gratefully acknowledged for support (K.C). Mathew Njoroge, Efrem Abay and Christel Brunschwig (H3-D ADME laboratories) are acknowledged for the metabolite identification studies and Carmen De Kock is acknowledged for the cytotoxicity studies.

\section{References}

1. World Health Organization. Global Tuberculosis Report; Technical Report from the World Health Organization: Geneva, Switzerland, 2014; Available at http://www.who.int/tb/publications/global_report/en/index.html

2. Russell, D. G.; Barry, C. E., III; Flynn, J. L. Science 2010, 328, 852.

3. Zumla, A.; Atun, R.; Maeurer, M.; Mwaba, P.; Ma, Z.; O’Grady, J.; Bates, M.;Dheda, K.; Hoelscher, M.; Grange, J. Trop. Med. Int. Health 2011, 16, 79.

4. (a) Dover, L. G.; Coxon, G. D. J. Med. Chem. 2011, 54, 6157-6165 (b) Yew, W. W.; Lange, C.; Leung, C. C. The European respiratory journal: official journal of the European Society for Clinical Respiratory Physiology 2011, 37, 441.

5. (a) Gandhi, N. R.; Nunn, P.; Dheda, K.; Schaaf, H. S.; Zignol, M.; van Soolingen, D.;Jensen, P.; Bayona, J. Lancet 2010, 375, 1830. (b) Udwadia, Z. F.; Amale, R. A.; Ajbani, K. K.; Rodrigues, C. Clin. Infect. Dis. 2012, 54, 579.

6. Nathanson, E.; Nunn, P.; Uplekar, M.; Floyd, K.; Jaramillo, E.; Lonnroth, K.; Weil, D.; Raviglione, M. N. Eng. J. Med. 2010, 363, 1050.

7. Raviglione, M.; Marais, B.; Floyd, K.; Lonnroth, K.; Getahun, H.; Migliori, G. B.; Harries, A. D.; Nunn, P.; Lienhardt, C.; Graham, S.; Chakaya, J.; Weyer, K.; Cole, S.; Kaufmann, S. H.; Zumla, A. Lancet 2012, 379, 1902.

8. Keshavjee, S.; Farmer, P. E. N. Engl. J. Med 2012, 367, 931.

9. (a) Stover, C. K.; Warrener, P.; VanDevanter, D. R.; Sherman, D. R.; Arain, T. M.; Langhorne, M. H.; Anderson, S. W.; Towell, J. A.; Yuan, Y.; McMurray, D. N.; Kreiswirth, B. N.; Barry, C. E.; Baker, W. R. Nature 2000, 405, 962. (b) Diacon, A.H.; Dawson R.; du Bois J.; Narunsky K.; Venter A.; et al. Antimicrob. Ag. Chemother. 2012, 56, 3027.

10. (a) Matsumoto, M.; Hashizume, H.; Tomishige, T.; Kawasaki, M.; Tsubouchi, H.; Sasaki, H.; Shimokawa, Y.; Komatsu, M. PLoS Med. 2006, 3, e466-1-14. (b) Diacon A.H.; Dawson R.; Hanekom M.; Narunsky K.; Venter A.' et al. International Journal of Tuberculosis and Lung Disease 2011, 15, 949.

11. Conde M.B.; Efron A.; Loredo C.; De Souza G.R.; Graca N.P.; et al. Lancet 2009, 373, 1183. 12. (a) Andries, K.; Verhasselt, P.; Guillemont, J.; Gohlmann, H. W. H.; Neefs, J.-M.; Winkler, H.; Van Gestel, J.; Timmerman, P.; Zhu, M.; Lee, E.; Williams, P.; de Chaffoy, D.; Huitric, E.; Hoffner, S.; Cambau, E.; Truffot-Pernot, C.; Lounis, N.; Jarlier, V. Science 2005, 307, 223. (b) Cohen, J. Science 2013, 339, 130. (c) Fox, G.J., Menzies, D. Infect Dis Ther. 2013; 2(2): 123.

13. (a) R. Goldman, R. P. Gabriel, Innovation Happens Elsewhere, Morgan Kaufman, San Francisco, 2005, ISBN: 1-55860-889-3 (b) Ballell,L.; Bates,R.H.; Young, R.J.;Alvarez-Gomez,D.; Alvarez-Ruiz, E. Barroso, V. et al Chem. Med. Chem. 2013, 8, 313 .

14. Dartois, V., Barry, C.E. 3rd, Bioorg. Med. Chem. Lett. 2013, 23, 4741.

15. El-Enany, M.M.; Kamel, M.M.; Khalil, O.M.; El-Nassan, H.B. Eur. J Med Chem 20112 (3), 331. 16. Williamson, D. S.; Parratt, M. J.; Bower, J. F.; Moore, J. D.; Richardson, C. M.; Dokurno, P.; Cansfield, A. D.; Francis, G. L.; Hebdon, R. J.; Howes, R.; Jackson, P.S.; Lockie, A. M.; Murray, J. B.; Nunns, C. L.; Powles, J.; Robertson, A.; Surgenor,A. E.; Torrance, C. J. Bioorg. Med. Chem. Lett. 2005, $15,863$.

* Corresponding author. Tel.: +27 21 6502553; fax: +27 21 6505195; email: kelly.chibale@uct.ac.za 
17. Paruch, K.; Dwyer, M. P.; Alvarez, C.; Brown, C.; Chan, T. Y.; Doll, R. J.; Keertikar, K.; Knutson, C.; McKittrick, B.; Rivera, J.; Rossman, R.; Tucker, G.; Fischmann, T.O.; Hruza, A.; Madison, V.; Nomeir, A. A.; Wang, Y.; Lees, E.; Parry, D.;Sgambellone, N.; Seghezzi, W.; Schultz, L.; Shanahan, F.; Wiswell, D.; Xu, X.;Zhou, Q.; James, R. A.; Paradkar, V. M.; Park, H.; Rokosz, L. R.; Stauffer, T. M.; Guzi, T. J. Bioorg. Med. Chem. Lett. 2007, 17, 6220.

18. Ali, S.; Heathcote, D. A.; Kroll, S. H.; Jogalekar, A. S.; Scheiper, B.; Patel, H.; Brackow, J.; Siwicka, A.; Fuchter, M. J.; Periyasamy, M.; Tolhurst, R. S.; Kanneganti, S. K.; Snyder, J. P.; Liotta, D. C.; Aboagye, E. O.; Barrett, A. G.; Coombes, R. C. Cancer Res. 2009, 69, 6208.

19.Wang, Y. D.; Honores, E.; Wu, B.; Johnson, S.; Powell, D.; Miranda, M.; McGinnis, J. P.; Discafani, C.; Rabindran, K.; Cheng, W.; Krishnamurthy,G. Bioorg. Med. Chem. 2009, 17, 2091. 20. Ramsey, S. J.; Attkins, N. J.; Fish, R.; van der Graaf, P. H. Br. J. Pharmacol. 2011, 164, 992. 21. Tellew, J. E.; Lanier, M.; Moorjani, M.; Lin, E.; Luo, Z.; Slee, D. H.; Zhang, X.; Hoare, S. R.; Grigoriadis, D. E.; St Denis, Y.; Di Fabio, R.; Di Modugno, E.; Saunders, J.; Williams, J. P. Bioorg. Med. Chem. Lett. 2010, 20, 7259.

22. Al-Adiwish, W.M.; Tahir, M.I.M.; Siti-Noor-Adnalizawati, A.F.; Hashim, S.M.; Ibrahim, N.; Yaacob, W.A. Eur J Med Chem 2013, 64, 464.

23. Boojamra, C. G.; Hui, H. C.; Jansa, P.; Mackman, R. L.; Parri sh, J. P.; Sangi, M.; Siegel, D.; Sperandio, D.; Yang, H. PCT Int. Appl, 2013 WO 2013096681 A1 20130627.

24. Tye, H.; Mueller, S. G.; Prestle, J.; Scheuerer, S.; Schindler, M.; Nosse, B.; Prevost, N.; Brown, C. J.; Heifetz, A.; Moeller, C.; Pedret-Dunn, A.; Whittaker, M. Bioorg. Med. Chem. Lett. 2011, 21, 34. 25. Kamouchi, M.; Kajioka, S.; Sakai, T.; Kitamura, K.; Kuriyama, H. Naunyn Schmiedebergs Arch. Pharmacol. 1993, 347, 329.

26. Shiota, T.; Yamamori, T.; Sakai, K.; Kiyokawa, M.; Honma, T.; Ogawa, M.;Hayashi, K.; Ishizuka, N.; Matsumura, K.; Hara, M.; Fujimoto, M.; Kawabata, T.;Nakajima, S. Chem. Pharm. Bull. (Tokyo) 1999, 47, 928.

27. Robins, R.K; Revankar, G.R.; O’Brien, D.E.; Spronger, R.H.; Novison, T.; Albert, A.; Senga, K.; Miller, J.P.; Streeter, D.G. J. Heterocyclic Chem. 1985, 22, 601.

28. Senga, K.; Novinson, T.; Wilson, H. R..; Robins, R.K. J. Med. Chem. 1981, 24(5), 610.

29. Ioerger, T. R., Y. Feng, K. Ganesula, X. Chen, K. M. Dobos, S. Fortune, W. R. Jacobs, Jr., V. Mizrahi, T. Parish, E. Rubin, C. Sassetti and J. C. Sacchettini. J. Bacteriol. 2010, 192, 3645.

30. (a) Collins, L., and S. G. Franzblau. Antimicrob. Agents Chemother. 1997, 41, 1004. (b)

Collins, L. A., M. N. Torrero, and S. G. Franzblau. Antimicrob. Agents Chemother. 1998, 42, 344.

31. Ishikawa, M., Hashimoto, Y. J. Med. Chem. 2011, 54, 1539.

32. Kondreddi, R.R.; Jiricek, J; Rao, S. P. S.; Lakshminarayana, S.B.; Camacho, L.R.; et al J.

Med.Chem. 2013, 56, 8849.

33. De Voss, J.J.; Rutter, K.; Schroeder, B.G.; Su, H.; Zhu, Y.; Barry, C.E. $3^{\text {rd }}$. Proc. Natl. Acad. Sci. U.S A. 2000, 97, 1252.

34. Ioerger, T. R.; O’Malley, T.; Liao, R.; Guinn, K.M.; Hickey, M. J.; Mohaideen, N.; Murphy, K. C.; Boshoff, H. I. M. ; Mizrahi, V.; Rubin, E. J.; Sassetti, C. M. Barry III, C. E.; Sherman, D. R. ; Parish, T.; Sacchettini, J. C. PLos One 2013, 8, e75245.

35. (a) Goldman, R.C. Tuberculosis (Edinb). 2013, 93(6), 569. (b) Arora, K.; Ochoa-Montaño, B.; Tsang, P.S.; Blundell, T.L.; Dawes, S.S.; Mizrahi, V.; Bayliss, T.; Mackenzie, C.J.; Cleghorn, L.A.; Ray, P.C.; Wyatt, P.G.; Uh, E.; Lee, J.;Barry, C.E. $3^{\text {rd }}$; Boshoff, H.I. Antimicrob Agents Chemother. 2014, 58(11), 6962.

36. Lee, R.E.; Protopopova, M.; Crooks, E.; Slayden, R.A.; Terrot, M.; Barry, C.E. 3rd J Comb Chem. 2003, 5(2), 172.

37. a.) Collins, L., and S. G. Franzblau. Antimicrob Agents Chemother 1997. 41, 1004. (b) Collins, L. A., M. N. Torrero, and S. G. Franzblau. Antimicrob Agents Chemother 1998. 42, 344.

38. Ioerger, T. R., Y. Feng, K. Ganesula, X. Chen, K. M. Dobos, S. Fortune, W. R. Jacobs, Jr., V. Mizrahi, T. Parish, E. Rubin, C. Sassetti and J. C. Sacchettini. J Bacteriol 2010. 192, 3645.

39. Hill, P.A. and Young, R.J. Drug Disc Today 2010. 15, 648.

40. Obach, S. Drug Metab. Dispos. 1999, 27, 1350.

41. Mosmann T. Journal of Immunological Methods 1983, 65, 55.

*Corresponding author. Tel.: +27 21 6502553; fax: +27 21 6505195; email: kelly.chibale@uct.ac.za 
42. Rubinstein L.V, Shoemaker R.H, Paull K.D, Simon R.M, Tosini S, Skehan P, Scudiero DA, Monks A, Boyd M.R Journal of the National Cancer Institute 1990, 82, 1113.

* Corresponding author. Tel.: +27 21 6502553; fax: +27 21 6505195; email: kelly.chibale@uct.ac.za 
